\title{
EFFECTS OF TWO HOST PLANTS ON SELECTED LIFE HISTORY CHARACTERISTCS OF Podisus maculiventris (SAY) (HETEROPTERA: PENTATOMIDAE). 1. WITHOUT ACCESS TO PREY
}

\author{
Fernando H. Valicente ${ }^{1}$ e Robert J. O'Neil ${ }^{2}$
}

\begin{abstract}
Effects of two different host plants, potato, Solanum tuberosum and tomato, Lycopersicon esculentum, on specific life history characteristics of the predator Podisus maculiventris (Say) were investigated. Without access to prey, survivorship was initially higher for predators provided potato or tomato plants than for predators provided water. However, no difference in survivorship was detected after the 35th day of life. Predators provided host plants lived up to 50 days, and predators provided water lived up 60 days. Predators provided host plants lost weight initially but then maintained a low weight throughout the reminder of their lives.
\end{abstract}

KEY WORDS: Insecta, predator, tradeoff, potato, tomato.

\section{RESUMO}

Efeito de Duas Plantas Hospedeiras em Caracteristicas Biológicas de Podisus maculiventris (Say) (Heteroptera: Pentatomidae) 1. Sem Acesso a Presa

Este trabalho objetivou estudar os efeitos de duas plantas hospedeiras, batata, Solanum tuberosum, e tomate Lycopersicon esculentum na biologia do predador. Podisus maculiventris (Say) sem acesso a presa. A sobrevivência foi inicialmente maior para predadores que se alimentaram em plantas de batata ou tomate do que predadores que se alimentaram somente com água. Entretanto, nenhuma diferença na sobrevivência foi detectada a partir do $35^{\circ}$ dia de vida. A longevidade dos predadores que se alimentaram de plantas foi de até 50 dias e, predadores que se alimentaram de água viveram até 60 dias. Predadores que foram providos com plantas perderam peso inicialmente, mantendo um peso baixo mas consistente até o fim de suas vidas. Predadores que não receberam nenhum alimento perderam peso continuamente até a morte.

PALAVRAS-CHAVE: Insecta, predador, batata, tomate.

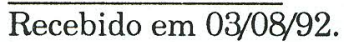

'EMBRAPA/CNPMS, Caixa postal 151, 35701-970, Sete Lagoas, MG.

${ }^{2}$ Department of Entomology, Purdue University, 47907, West Lafayette, IN, U.S.A. 


\section{INTRODUCTION}

The importance of $P$. maculiventris as a predator in field crops is stressed by many authors (Morril 1906, Mukerji \& Leroux 1965, Ables \& McCommas 1982). Like many insect predators with piercing-sucking mouthparts, $P$. maculiventris can also feed on plants when there is not enough prey available in the field. Olsen (1910) observed $P$. maculiventris nymphs with their mouthparts inserted on stems of evening primose (Onagra biennis) up to four minutes. He also observed $P$. maculiventris feeding on the leaves of other plants. Later, Stoner (1930) described P. maculiventris nymphs with their mouthparts inserted into the petiole of a spring of celery. Young predators (less than 10 days old) were not observed to feed upon insect larvae. Morris (1963) observed P. maculiventris inserting their mouthparts into the mid-vein of an apple leaf, and apparently feeding for a few minutes to up to three hours. This was not a starvation phenomenon as it was observed at all prey densities. Older predators spent more time feeding on the plant than younger individuals. $P$. maculiventris adults between 20-40 days old spends $9-16 \%$ of its time feeding on plant. Ruberson et al. (1986) studied plant feeding by $P$. maculiventris and pre-ovipositional period. Plant feeding enhanced survival and shortened pre-ovipositional period. When provided with potato foliage with prey, Leptinotarsa decemlineata (Say), and water, pre-imaginal survival increased by $27.5 \%$.Wiedenmann (1990) found that $P$. maculiventris spent an increased time feeding on Phaseolus vulgaris (lima beans) at lower prey densities. Based on the information above, the objectives of this work were to evaluate some life history characteristics as: survival, longevity and body wieght of $P$. maculiventris provided different host plants without any prey.

\section{MATERIAL AND METHODS}

Effects of different host plants on body weight and longevity were measured by isolating a single predator on the host plant in the absence of prey. Predators were provided with either water or a sprig (ca. $10 \mathrm{~cm}$ long) of potato or tomato. Water was provided through a cotton wick. Plant sprigs and cotton wick were placed in a water-filled covered plastic container $(4 \mathrm{~cm}$ in diameter and $4 \mathrm{~cm}$ in depth) with a hole in the center lid. P. maculiventris were kept individually in a inverted clear plastic container $(12 \mathrm{~cm}$ in diameter and $14 \mathrm{~cm}$ in depth) placed over the host plants or water. A control consisted of predators with no plants or water provided. Predators were weighed every three days using a Mettler AE 100 balance (precision \pm 0.1 $\mathrm{mg}$ ) and the number of living specimens were recorded daily. Plants and water were changed every three days. Predators were observed occasionally to determine if they were feeding on plants or the cotton wick. Each treatment consisted of sixteen replicates in a randomized complet block design. Mean longevity, average and final living body weight were compared using analysis of variance. Treatment means were compared by Duncan's new range test. All treatments were judged at $\mathrm{P}=0,05$ level of significance. In addition to ANOVA, predators survivorship, and body weight were 
plotted against time to better visualize the effect of different host on these life history traits.

\section{RESULTS}

Predators were observed to feed on host plants from 2 to 30 minutes. Similarly, predators inserted the mouthparts in the cotton wick where water was available. In general, predators were very active and were observed to feed on leaves and stems of potato or tomato plants. $P$. maculiventris provided no food survived an average of 9.1 days and lived significantly shorter than predators provided either plants or water (Table 1). Predators provided potato plants lived an average of 31.9 days and did not live significantly longer than predators provided tomato plants. Predators provided water lived an average 27.1 days.

Table 1. Average ( \pm S.E.) longevity of unmated female $(\mathrm{N}=16)$ Podisus maculiventris provided, no food (check), potato or tomato plants, or water.

Host

Average longevity ${ }^{1}$

(days)

Potato plants

Tomato plants

Water

Check

$31.9(1.86)$ a

$28.8(2.47)$ a

$27.1(3.53)$ a

$9.1(0.28) \mathrm{b}$

${ }^{1}$ Means followed by different letters within a column are significantly different using Duncan's new multiple range test.

Survivorship curves are shown in Fig. 1. Survivorship of $P$. maculiventris provided no food was shifted to the left before the 10 days of life suggesting a lower survivorship compared to the predators provided host plants, or water. Survivorship of $P$. maculiventris provided potato plants was higher (further to the right) than the survivorship of the predators provided tomato plants or water. All predators provided potato plants lived up to 26 days, while approximately $50 \%$ of predators fed tomato or water were dead by this time. However, survivorship after the 40th day of predators provided water, potato or tomato plants was similar. No diference in mean body weights between predators provided no food $(41.2 \mathrm{mg})$ and predators provided water $(42.8 \mathrm{mg})$ was observed. Predators provided potato or tomato plants weighed an average $48.5 \mathrm{mg}$ and $45.1 \mathrm{mg}$ with, respectively. Mean body wieghts were significantly higher for predators provided plants than predators with no food or water (Table 2). Plots of average body weight showed that predators provided no food lost weight continually until death. Predators provided host plants, or water lost weight initially, but maintained a low body weight throughout the lifetime (Figs. 2A,B). 


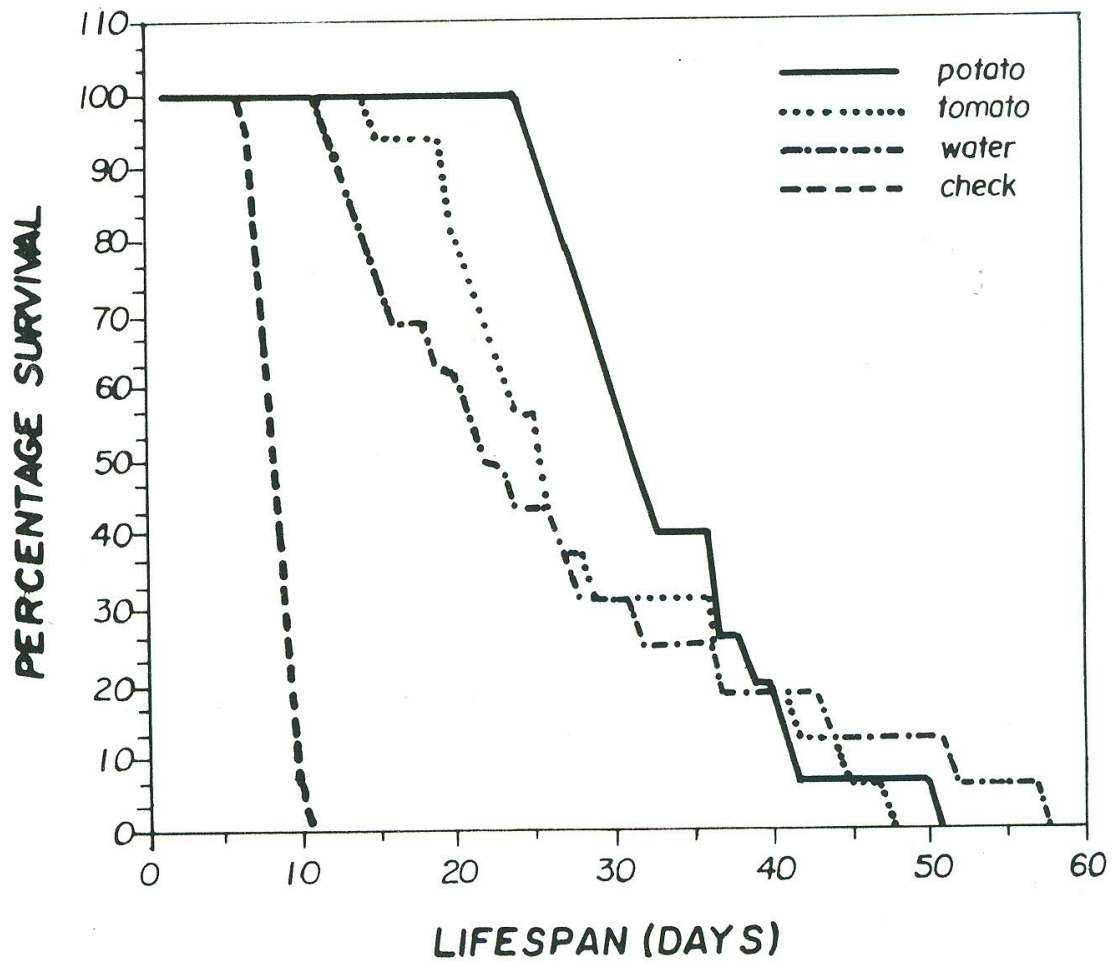

Figure 1. Survivorship curves of female Podisus maculiventris provided, no food (check), potato or tomato plants, or water.

The final living weight was not significantly different for $P$. maculiventris provided potato or tomato plants. ANOVA showed that the final living weight was significantly higher for $P$. maculiventris provided potato plants than predators provided no food or water (Table 2).

Table 2. Average ( \pm S.E.) body weight and final living of unmated female $(\mathrm{N}=16)$ Podisus maculiventris provided, no food (check), potato or tomato plants, or water.

\begin{tabular}{lll}
\hline Host & $\begin{array}{c}\text { Average weight }(\mathrm{mg})^{1} \\
\text { (S.E.) }\end{array}$ & $\begin{array}{c}\text { Average final living } \\
\text { weight (mg) (S.E.) }\end{array}$ \\
\hline Potato plant & $48.48(2.44) \mathrm{a}$ & $46.60(3.6) \mathrm{a}$ \\
Tomato plant & $45.10(1.48) \mathrm{ab}$ & $41.66(1.9) \mathrm{ab}$ \\
Water & $42.77(1.54) \mathrm{b}$ & $37.87(1.6) \mathrm{bc}$ \\
Check & $41.61(1.81) \mathrm{b}$ & $33.43(1.5) \mathrm{c}$ \\
\hline
\end{tabular}

${ }^{1}$ Means followed by different letters within a column are significantly differente using Duncan's new multiple range test. 

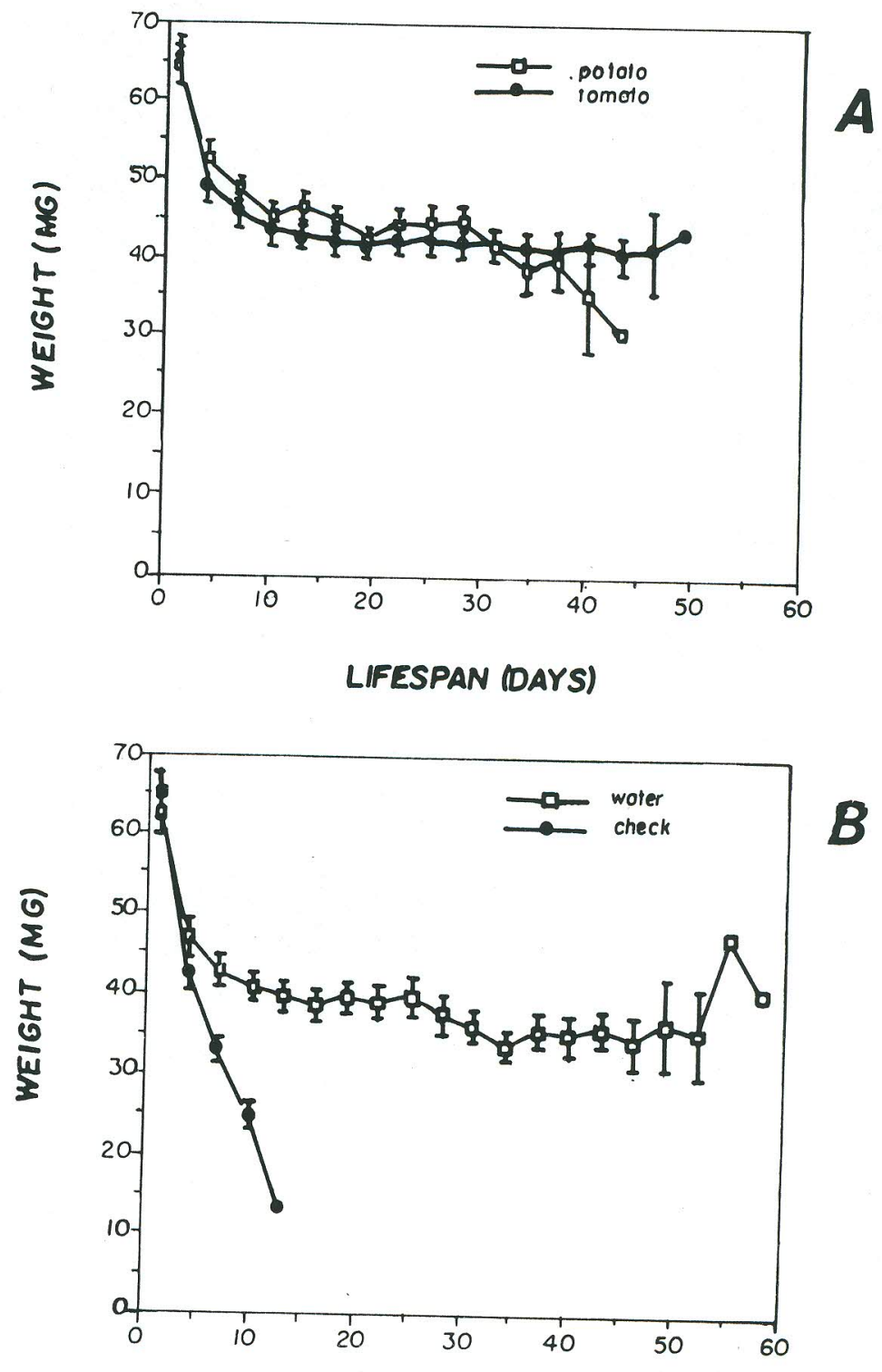

\section{LIFESPAN (DAYS)}

Figure 2. Mean body weight ( \pm S.E.) (mg) over time(days) of unmated female Podisus maculiventris provided, potato plants (A) and predators provided no food (check), or water (B). 


\section{DISCUSSION}

Longevity was significantly higher for predators provided potato or tomato plants, or water than predators provided no food (Table 1). Results showed that $P$. maculiventris adults can survive up to 50 days when provided only potato or tomato plants, and were able to live up to 60 days when water was provided (Fig. 1). Predators provided no source of moisture had lower survivorship rate than predators provided host plants or water. Survivorship of predators provided no source of moisture decreased before the 10th day of life (Fig. 1). In general, for predators provided moisture (plants or water), survival was similar throughout predators lifespan (Fig. 1). The shape of the survivorship curves were similar for predators provided potato or tomato plants, or water. Predators provided plants or water showed "type I" survivorship curve (convex) in which mortality was delayed and predators died at an older age (Begon et al. 1990). Predators provided no source of moisture showed a "type III" (concave) survivorship curve, which indicates high mortality early in life (Begon et al. 1990). Survivorship was higher during the first 30 days of life for predator provided potato plants. However, survivorship was similar after the 40th day of life for predators provided water, potato or tomato plants.

Mean body weight of $P$. maculiventris provided host plants or water, decreased drastically during the first ten days of life and was maintained consistently low throughout their lifetime (Figs. 2A, B). Predators provided no source of moisture lost weight continuously until death. Although predators provided host plants or water showed no differencein longevity (Table 1), the average body weight and final living body weight showed that there was a difference between predators provided potato plants and predators provided water (Table 2). These results suggest that $P$. maculiventris may get some nutritional factors when provided host plants, particularly potatoes, compared to predators provided no host plants or water. Sequestration of nutrients from host plants by $P$. maculiventris has been suggested by Ruberson et al. (1986), who reported the evidence that plant feeding enhanced nymphal survival and reduced the pre-ovipositional period. However, in the present study any nutritional factors sequestered by $P$. maculiventris from plants did not enhance longevity, because longevity of predators provided plants was not significantly different from predators provided water (Table 1 ). The capacity of $P$. maculiventris to maintain longevity with no prey as long as they have access to moisture may be attributed to a strategy to use alternative or moisture sources when prey are scarce. In prey-scarce environments, the ability of $P$. maculiventris to use host plants may be crucial to allow the predators to prolong survival prior to the occurrence of prey. Taking advantage of available moisture sources, $P$. maculiventris might be able to persist longer in prey-scarce environments, to allow reproduction to occur when prey become more readily available. 


\section{LITERATURE CITED}

Ables, J.R. \& D.W. McCommas. 1982. Efficacy of Podisus maculiventris as a predator of variegated cutworm on greenhouse cotton. J. Ga. Entomol. Soc. 17: 200-204.

Begon, M., J.L. Harper \& C.R. Townsend. 1990. Ecology, individuals, populations and communities. 2nd ed. Boston, Massachusetts, U.S.A. Sinauer Associates, Inc. 945 p.

Morril, A.W. 1906. Some observations on the spined soldier bug (Podisus maculiventris Say). USDA Bur. Entomol. Bull. 60: 155-161.

Morris, R.F. 1963. The effect of predator age and prey defense on the functional response of Podisus maculiventris (Say) to the density of Hyphantria cunea. Can. Entomol. 95: 1009-1020.

Mukerji, M.K. \& E. J. LeRoux. 1965. Laboratory mating of a Quebec strain of the pentatomid Podisus maculiventris (Say) (Hemiptera: Pentatomidae). Phytoprotection 46: 40-60.

Olsen, C.E. 1910. Notes on breeding Hemiptera. J.N.Y. Entomol. Soc. 18: 30-42.

Ruberson, J.R.. M.J. Tauber \& C.A. Tauber. 1986. Plant feeding by Podisus maculiventris (Heteroptera: Pentatomidae): Effect on survival, development, and preoviposition period. Environ Entomol. 15: 894897.

Stoner, D. 1930. Spined soldier bugs reared on celery leaf-tyer. Fla. Entomol. 14: 21-22.

Wiedenmann, R.N. 1990. Searchig strategy of the generalist predator Podisus maculiventris (Say) (Heteroptera: Pentatomidae). PhD dissertation. Purdue University, Indiana, U.S.A. 